\section{УАК 551.311.231:553.08}

М. М. ЗІНЧУК, д-р геол.-мінерал. наук, професор, академік АН РС (Я), голова Західноякутського наукового центру Академії наук Республіки Саха (Якутія), м. Мирний, nnzinchuk@rambler.ru, https://orcid.org/0000-0002-9682-3022

\title{
ЩОДО ВИКОРИСТАННЯ ФОРМАЦІЇ ДАВНІХ КІР ВИВІТРЮВАННЯ ПІД ЧАС ПОШУКІВ АЛМАЗНИХ РОДОВИЩ
}

\author{
ОБ ИСПОЛЬЗОВАНИИ ФОРМАЦИИ ДРЕВНИХ КОР ВЫВЕТРИВАНИЯ \\ ПРИ ПОИСКАХ АЛМАЗНЫХ МЕСТОРОЖДЕНИЙ
}

\section{ABOUT USE OF ANCIENT WEATHERING CRUSTS FORMATION DURING DIAMOND-PROSPECTING WORKS}

\begin{abstract}
Комплексні дослідження пізньодевонських-ранньокам'яновугільних і середньо-пізньотріасових кір вивітрювання (КВ) на різних породах (теригенно-карбонатні утворення, долерити, туфи, туфогенні утворення й кімберліти) показали, що в умовах теплого й вологого клімату утворилися відповідні елювіальні формації. Складний багатокомпонентний склад первинних порід зумовив під час короутворення уповільнене перетворення первинного матеріалу, унаслідок чого формування КВ призупинялося найчастіше на початкових стадіях. Розвиток неповних профілів вивітрювання викликано насамперед слабким винесенням двовалентних катіонів з первинних мінералів. Визначені типоморфні відмінності в складі кожного типу КВ можна успішно використовувати для вдосконалення методики пошукових робіт на алмази. Важливого значення водночас набувають питання встановлення умов розмиття й перевідкладення продуктів вивітрювання різних порід у корелятивні товщі верхнього палеозою й мезозою головних алмазоносних районів Сибірської платформи. Під час формування продуктів перемивання й перевідкладення в умовах накопичення делювіально-пролювіальних, пролювіально-алювіальних та озерних фацій поблизу кімберлітових трубок утворювалися розсипи алмазів. За рясного внесення чужого для регіону теригенного матеріалу в алювіальних фаціальних товщах розмивний кімберлітовий матеріал дуже розубожувався завдяки неалмазоносним утворенням. Найбільші концентрації місцевого (зокрема й кімберлітового) матеріалу зафіксовані в базальних горизонтах нижньопалеозойської лапчанської світи, яка є формацією давніх КВ. У мезозойський час у межах північно-західного борту Ангаро-Вілюйського накладеного мезозойського прогину (АВНМП) формування відкладень, збагачених продуктами перемивання й перевідкладення КВ, відбувалося в його північно-східній прибортовій частині. У цій структурно-формаційній зоні були найсприятливіші умови для концентрації елювіальних продуктів і формування алмазоносних розсипів. В іншій південно-східній зоні АВНМП, де алювіальними потоками за межі регіону виносився місцевий матеріал, умови для формування алмазоносних розсипів були несприятливими. Усе це підкреслює важливість завдань вивчення формації давніх КВ під час прогнозування й пошуків алмазних родовищ.

Ключові слова: кори вивітрювання, теригенно-карбонатні породи, долерити, туфи, туфогенні утворення, кімберліти, пошукові роботи, алмази.
\end{abstract}

Complex research of Late Devonian - Early Carboniferous and Middle-Late Triassic weathering crusts on various rocks (terrigenous-carbonate formations, dolerites, tuffs, tuffaceous formations and kimberlites) indicated that in conditions of warm and humid climate corresponding formations of weathering crusts were generated. Complicated multicomponent composition of primary rocks conditioned slow transformation of initial material during crust formation, whereby formation of weathering crusts suspended, often at starting stages. Development of incomplete profiles of weathering was caused, first of all, by weak removal of bivalent cations from primary minerals. Newly arising phases will be dioctahedral and quite often preserve mixed constitution of structural cations. Established typomorphic differences in composition of each type of weathering crusts may be successfully used when upgrading technique of prospecting works on diamonds. At the same time, the issues of establishing the erosion and redeposition of the weathering products of the various rocks into correlative trills of the upper paleoscale of the main diamondiferous regions of the Siberian platform and becoming more important. During the formation of products of washout and redeposition under conditions of accumulation of deluvial-proluvial, proluvial-alluvial and lacustrine factions near kimberlite pipes, diamond placers were formed. With an abundant introduction of terrigenous material alien to the region in alluvial facies strata eroded kimberlite material was greatly diluted due to non-diamondiferous formations. The highest concentrations of local (including kimberlite) material are recorded in the basalt horizons of the Lower Paleozoic Lapchansk Formation which is a formation of woody weathering crusts. In the Mesozoic with the northeastern flank of the Angara-Vilyni superimposed Mesozoic trough the formation of deposits enriched with the products of products of washout and redeposition of CV zone, there were the most favorable. In this structural-formation concentration of eluvial products and the formation of diamond-bearing placers. In the other southern zone of the AVNMP, where alluvial flows outside the region are carried out local material, the conditions for the formation of diamond-bearing placers were unfavorable. All this underlines the importance of studying the formation of ancient Weathering crusts in fore casting and approaching diamond deposits.

Keywords: weathering crusts, terrigenous-carbonate rocks, dolerites, tuffs, tuffaceous formations, kimberlites, prospecting works, diamonds.

На древних платформах мира в алмазоперспективных районах широким развитием пользуются древние коры выветривания (KB) на различных породах [5-7, 14-17,28], а также отложения, обогащенные продуктами их размыва и пе-

М. М. Зінчук, 2021, с. 24-32 реотложения в различных фациальных обстановках [18-22, 26-29]. Интенсивность выветривания обычно резко возрастает с увеличением температуры и количества выпадающих осадков $[4,10-12]$. Большое значение при этом имеет также обилие гумусового вещества, обладающего кислотными свойствами. Мощность КВ во многом зависит от глубины 
залегания грунтовых вод. Наиболее мощная КВ формируется на водоразделах, в то время как интенсивная денудация элювиальных продуктов происходит вдоль эрозионной сети, а на плоских водоразделах наблюдается минимальный размыв при наиболее интенсивном дренаже. Сохраняются от размыва элювиальные продукты только при стечении благоприятных факторов и, преимущественно, в понижениях древнего рельефа и в тектонически опущенных блоках. Наиболее детально КВ в алмазоносных регионах изучены в Малоботуобинском (МБАР), Далдыно-Алакитском (ДААР) и Средне-Мархинском (СМАР) районах Сибирской платформы (СП), в которых благоприятные палеогеографические условия для формирования выветрелых толщ существовали в позднедевонское-раннекаменноугольное и средне-позднетриасовое время. Поскольку на рассматриваемой территории в конце девона произошло сокращение морского бассейна [1-3, 23], то на северо-западе и северо-востоке Тунгусской верхнепалеозойской синеклизы (ТВС) сформировались прибрежные низменные равнины, а на юге как этой, так и Вилюйской мезозойской наложенной синеклизы (ВМНС) возникли равнины с континентальным осадконакоплением, которые разделялись более высокими денудационными плато. Каменноугольному периоду активизации общего воздымания СП предшествовала эпоха относительного покоя, в течение которой практически не происходило дифференцированных тектонических движений. Выравнивание пенепленизированного рельефа и образование элювия на исходных породах протекало постепенно на протяжении всего периода формирования территории, при котором продукты КВ поступали в коррелятивные толщи равномерно, что связано с незначительными в это время изменениями тектонического режима и палеорельефа. Поэтому отложения нижнего карбона ТВС отражают погребенную поверхность выравнивания на границе девона и карбона и по всему разрезу обогащены продуктами выветривания, представляя тем самым формацию древних КВ [7-12, 25]. Общая картина осадконакопления в карбоне (по сравнению с девоном) изменялась мало. На территории ТВС в карбоне и перми широкое развитие получили низменные заболоченные равнины с угленосными отложениями. В конце пермского периода во многих районах СП начались излияния лав и внедрение траппов (особенно сильно проявившиеся к началу раннего триаса). К концу этого периода длительная эпоха денудации завершилась пенепленизацией СП. Региональная пенепленизация в среднем и позднем триасе обусловлена эпохой относительного тектонического покоя, предшествующая юрской активизации СП. В этот же период происходило формирование мощной $\mathrm{KB}$, причем корообразование, денудация и переотложение элювиальных продуктов в коррелятивные толщи происходили относительно равномерно, что было обусловлено (как и в позднем девоне - раннем карбоне) слабым изменением палеорельефа и тектонического режима. Поэтому ирелях ская свита рэт-геттанга Ангаро-Вилюйского наложенного мезозойского прогиба (АВНМП), наиболее обогащенная продуктами переотложения КВ (являющаяся формацией КВ и продуктов их переотложения), - отражение погребенной денудационной поверхности среднего-верхнего триаса.

В пределах упомянутых выше основных алмазоносных районов СП, расположенных в пределах Якутской алмазоносной провинции (ЯАП), древние КВ развиты на различных породах: терригенно-карбонатных нижнего палеозоя, долеритах, туфах и туфобрекчиях трубчатых тел, туфоген- ных образованиях корвунчанской свиты и кимберлитах. В структурном плане древние КВ приурочены преимущественно к конседиментационным палеоподнятиям [7-13], в пределах которых в период формирования перекрывающих их отложений развивались обстановки денудационных и денудационно-аккумулятивных равнин. В конседиментационных палеоподнятиях, служивших местами аккумуляции переотложенного материала КВ, были неблагоприятные условия для интенсивного корообразования. Например, в позднедевонское-раннекаменноугольное время в МБАР относительно наиболее полные и мощные (до 15 м) площадные остаточные КВ на терригенно-карбонатных породах нижнего палеозоя развивались (а затем сохранились от размыва) на Мирнинском, Улу-Тогинском, Джункунском и Чернышевском палеоподнятиях, обрамлявших Ботуобинскую, Улу-Тогинскую, Джункунскую и Ахтарандинскую впадины (рис. 1). При этом в отдельных разрезах устанавливаются верхние горизонты КВ, свидетельствующие о формировании в них полных профилей. Подобные палеогеоморфологические особенности развития и распределения характерны и для

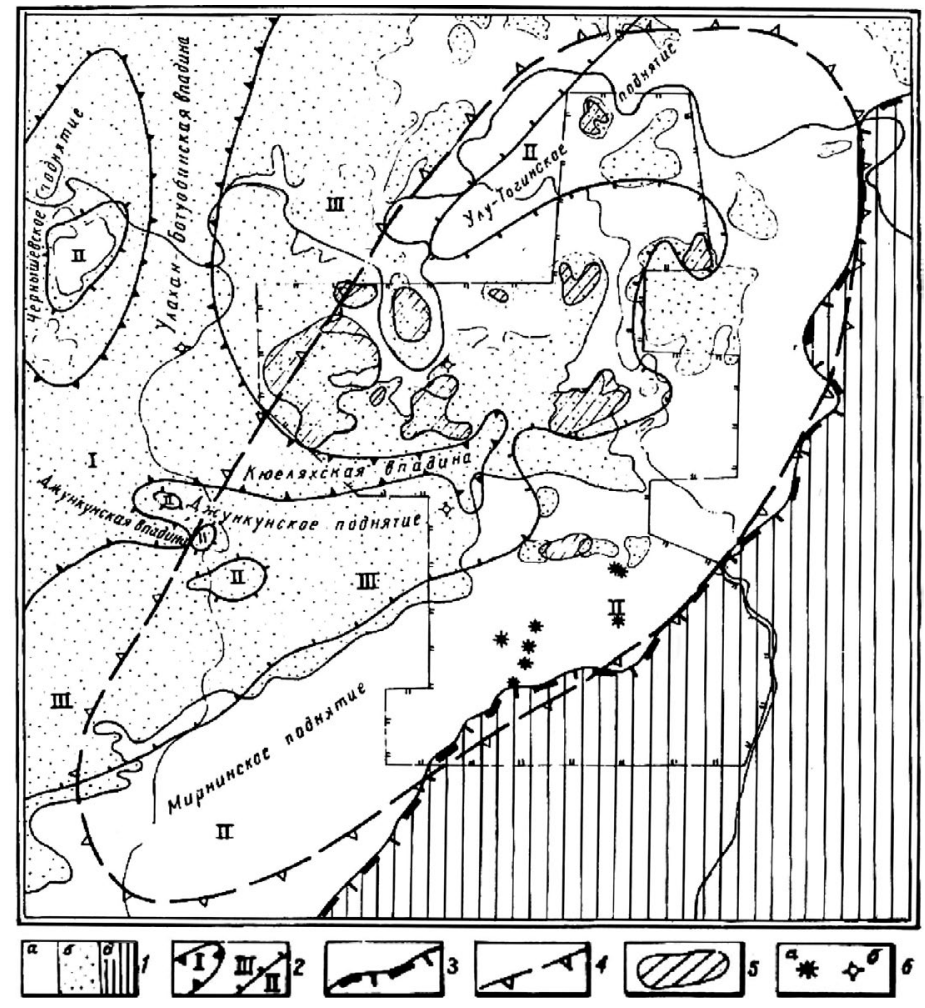

Рис.1.Карта поверхностей позднедевонско-раннекаменноугольного выравнивания и КВ МБАР [8]:

1 - поверхности выравнивания и развитые на них КВ верхнего девона - нижнего карбона (a - частично уничтоженные и перекрытые верхнепалеозойскими отложениями; б - отпрепарированные и в значительной степени уничтоженные более поздними денудационными процессами; в - полностью уничтоженные в период дорэтского среза территории в пределах центральной части АВМП); 2 - площади территориально совпадающие с конседиментационными палеовпадинами, а также с верхними и нижними частями конседиментационных палеоподнятий, в пределах которых условия для развития и сохранения КВ и продуктов их ближнего переотложения были неблагоприятные (I), благоприятные (II), весьма благоприятные (III); 3 - северо-западная граница центральной части АВМП; 4 - граница Нижне-Ботуобинского неотектонического поднятия; 5 - поля развития $\mathrm{KB}$ на терригенно-карбонатных породах нижнего палеозоя; 6 - трубки взрыва (а - кимберлитов, б - трапповых пород) 
средне-позднетриасовых КВ на аналогичных породах, которые в МБАР формировались (рис. 2) в двух различных структурно-формационных зонах [11-13], резко отличающихся условиями развития и сохранения элювиальных продуктов. Одна из них охватывает всю северо-западную половину территории района и в структурном отношении совпадает с северо-западным бортом АВНМП, являвшегося на протяжении длительного времени (норий-ранний лейас)
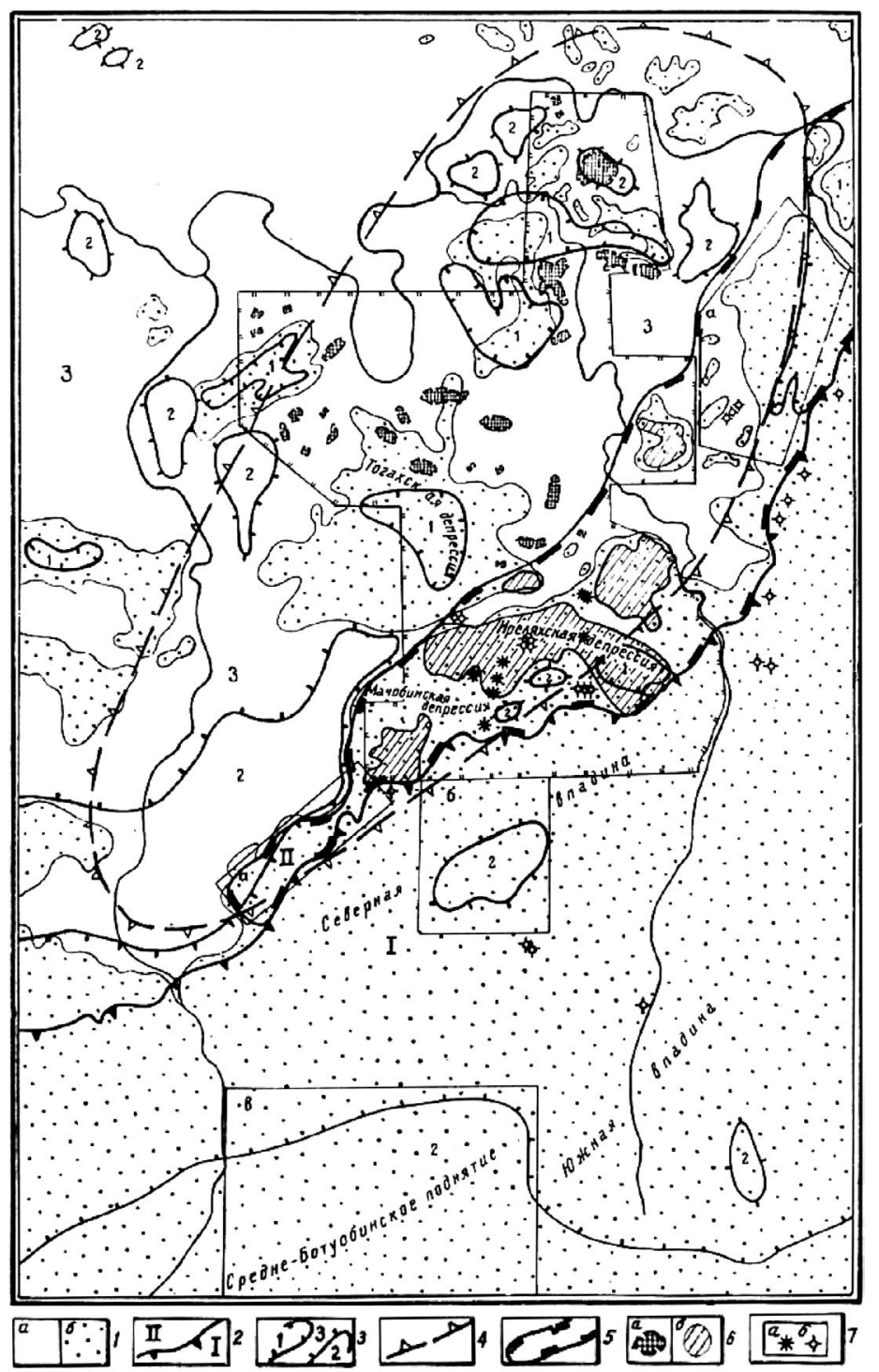

Рис. 2. Карта поверхностей средне-позднетриасового выравнивания и КВ МБАР [9]:

1 - поверхности выравнивания и развитые на них КВ среднего-верхнего триаса, в значительной степени уничтоженные более поздними денудационными процессами: а - перекрытые верхнетриасовыми-нижнеюрскими отложениями, б - отпрепарированные; 2 - граница двух структурно-формационных зон: I - юго-восточной, территориально совпадающей с центральной частью АВМП; II - северо-западной, охватывающей северо-западный борт этого прогиба, преимущественно трапповое плато; 3 - площади, в пределах которых условия для развития и сохранения КВ и продуктов их ближнего переотложения были неблагоприятными (1), благоприятными (2) и весьма благоприятными (3); 4 - граница Нижне-Ботуобинского неотектонического поднятия; 5 - граница площади распространения преимущественно терригенно-карбонатных пород нижнего палеозоя; 6 - поля развития KB на долеритах и туфах нижнего триаса (a), на терригенно-карбонатных породах нижнего палеозоя (б); 7 - трубки взрыва: трапповых (а) и кимберлитовых (б) пород денудационной, и только в плинсбахе - денудационно-аккумулятивной поверхностью. Здесь ко времени корообразования были развиты верхнепалеозойские терригенно-вулканогенные отложения, а также породы трапповой формации (долериты, туфы и туфогенные образования) нижнего триаса. Только в полосе шириной примерно 25-30 км вдоль бровки северо-западного борта АВНМП в то время обнажались терригенно-карбонатные породы нижнего палеозоя, подвергающиеся интенсивному корообразованию. Вторая - юго-восточная зона района, совпадающая с центральной частью АВНМП, где в среднем и позднем триасе обнажались терригенно-карбонатные породы нижнего палеозоя, была неблагоприятной для интенсивного корообразования. В процессе выветривания разрушенный материал субстрата сносился в пониженные участки центральной части прогиба. Возможно, на небольших поднятиях в прогибе КВ она могла достигать значительной мощности. В ДААР также устанавливается приуроченность КВ к палеоподнятиям и их склонам. Поля развития площадных остаточных КВ на терригенно-карбонатных породах ордовика и силура тяготеют к Чукук-Мархинскому и Верхне-Алакитскому поднятиям и их склонам, на которых устанавливаются фрагменты более мощных (до 15 м) и широких (по площади) элювиальных толщ, а в ближайших депрессиях отмечается аккумуляция продуктов их переотложения.

В позднедевонское-раннекаменноугольное время на большей части территории Непско-Ботуобинской и Анабарской антеклиз и их склонов, а также почти на всей площади МБАР и ДААР выветриванию подвергались повсеместно обнажавшиеся терригенно-карбонатные породы нижнего палеозоя. В средне-позднетриасовое время корообразование на этих породах происходило только в юго-восточной части МБАР. Из-за значительно большего эрозионного среза пород в допозднепалеозойское время, чем в дораннеюрское, сохранность средне-позднетриасовых КВ оказалась здесь значительно лучшей, чем позднедевонских-раннекаменноугольных. В целом эти КВ вместе с перекрывающими их отложениями фиксируют поверхность последних циклов денудации этих двух глобальных и продолжительных эпох выветривания, приведших к формированию разновозрастных формаций КВ и продуктов их переотложения. Комплексные исследования многих профилей выветривания этих пород показали, что несмотря на различный возраст, условия формирования и сохранности $\mathrm{KB}$, есть общие их свойства и минеральный состав. В легкой фракции продуктов КВ терригенно-карбонатных пород повышены концентрации полуокатанных и окатанных зерен кварца и халцедона, а также угловатых обломков опала. Здесь отмечено и повышенное, по сравнению с другими выветрелыми толщами, содержание кислых плагиоклазов (альбита и плагиоклаза) и санидина, которые в верхних горизонтах разрезов чаще всего регенерированы и изменены. Зерна плагиоклазов обычно имеют неправильную форму со сглаженными углами. Слабо выветрелым терригенно-карбонатным породам свойственно также присутствие вторичных сульфатных минералов - алюминита, паралюминита, базалюминита, ярозита и др. Для тяжелой фракции довольно характерны полуокатанные и окатанные зерна апатита, альмандина, турмалина, циркона, эпидота, а также повышенные концентрации аутигенного пирита, сидерита, барита и ярозита. В отдельных разрезах отмечены также единичные пластинчатые обломки хлоритоида, брусита, муассанита, не встре- 
ченные в КВ других типов. Присутствующий в терригенно-карбонатных породах триоктаэдрический и в основном раннекатагенетический тонкодисперсный хлорит, образующий в породах цемент, быстро разлагается в зоне гипергенеза. Поэтому пелитоморфные продукты выветривания этих пород представлены исключительно диоктаэдрическими минералами. На самой ранней стадии выветривания - это первичные минералы (гидрослюды и монтмориллонит-гидрослюдистое смешанослойное образование - МГСО), а на более поздних стадиях и вторичные минералы (типа каолинита). Особенностью глинистой составляющей КВ терригенно-карбонатных пород, независимо от времени их формирования, следует считать повсеместное присутствие в её составе диоктаэдрической гидрослюды $2 \mathrm{M}_{1} \mathrm{c} \mathrm{Al}$ и $\mathrm{Fe}^{3+}$ в октаэдрических позициях. Весьма характерным минералом в продуктах выветривания этих пород является также МГСО с различной тенденцией к упорядоченности (рис. 3), что показывает выветривание терригенно-карбонатных пород, резко отличающееся от характера изменения в гипергенных условиях магматических пород региона (долеритов, туфов и туфогенных образований, а также кимберлитов). Вектор преобразования терригенно-карбонатных пород направлен непосредственно к полю каолинита, что в целом соответствует известной закономерности его образования при выветривании кислых и близких к ним (по химическому составу) осадочных пород. Этот вывод подтверждается нашими данными о закономер-
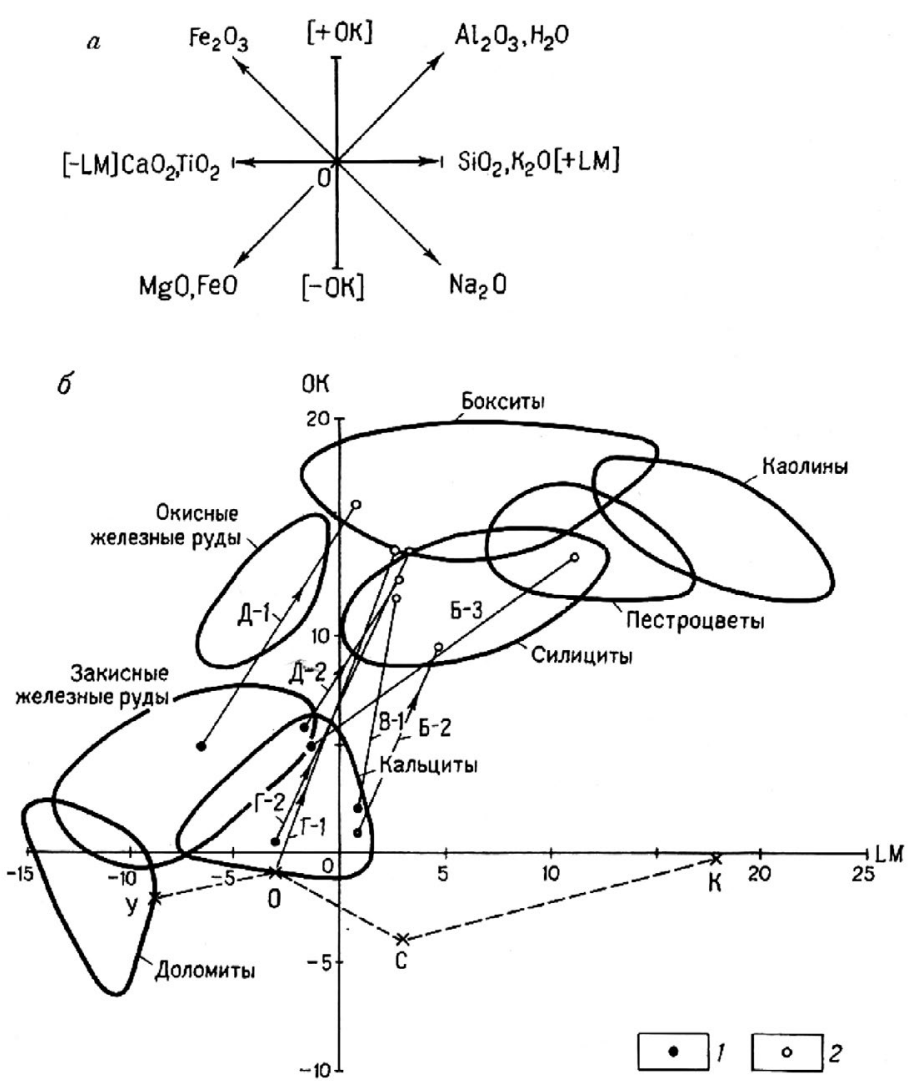

Рис. 3. Вариационная диаграмма LМ-ОК химического состава пород и продуктов их изменения в земной коре [24]

а - векторы породообразующих окислов на диаграмме; б - распределение химических составов продуктов выветривания терригеннокарбонатных пород (Б), долеритов (В), туфов и туфогенных образований (Г) и кимберлитов (Д). Породы: У - ультраосновные, О - основные, С - средние, К - кислые; Б-2 - скв. 432/192; Б - 3 - скв. 114/176; В-1 - скв. 202/44; Г-1 - скв. Ан-50; Г-2 - скв. 280/188; Д-1 - скв. А-63К Д-2 - шахта 102. 1 - исходные породы, 2 - выветрелые продукты ном развитии каолинита в наиболее полных профилях КВ терригенно-карбонатных пород.

Учитывая общие черты в вещественном составе продуктов выветривания пород трапповой формации (туфов, туфогенных образований и долеритов), целесообразно рассматривать их минералого-геохимические особенности совместно, акцентируя внимание не только на отличительных чертах состава, характеристике первичных минералов, но и на некоторых аспектах строения и кристаллической структуры, что подчеркивает главнейшие типоморфные признаки элювиальных продуктов. Характерными минералами легкой фракции выветрелых пород трапповой формации являются в различной степени измененные плагиоклазы (от андезина до битовнита) и гейландит. Вверх по разрезам в породах обычно увеличивается содержание олигоклаза, что связано с меньшей устойчивостью средних и основных плагиоклазов. В слабоизмененных зернах плагиоклазов довольно часто наблюдаются полисинтетические двойники. Гейландит в породе представлен мелкими угловатыми пластинчатыми обломками неправильной формы. Довольно характерными для КВ туфов и туфогенных пород можно считать также выделения аллофана. Типоморфным минералом тяжелой фракции пород трапповой формации является ильменит $[5,10]$. В КВ долеритов обычно доминируют толстотаблитчатые и пластинчатые кристаллы минерала с хорошо развитыми гранями и угловатые обломки с реликтами огранки. В КВ туфов и туфогенных пород зерна ильменита преимущественно неправильной формы со сглаженными краями, реже - остроугольные обломки. Довольно характерна для выветрелых пород трапповой формации значительная концентрация амфиболов, моноклинных пироксенов, эпидота, клиноцоизита, цоизита, турмалина, циркона, дистена и вулканического стекла. Среди тяжелых аутигенных минералов резко доминируют разнообразные выделения гидроксидов железа, что придает им буроватую окраску. Для глинистых минералов из слабоизмененных долеритов таким является $\mathrm{Mg}-\mathrm{Fe}^{3+}$-монтмориллонит [8-14], ассоциирующий с вермикулитом. Обе фазы являются сегрегированными друг от друга и в структурном отношении представляют механическую смесь. По мере возникновения в верхних частях наиболее полных измененных профилей выветривания пакетов монтмориллонита в пределах всего объёма кристаллов, микроблоки вермикулита распадаются на отдельные слои, сохраняющие, несмотря на сопровождающую этот процесс их существенную диоктаэдризацию, реликтовую структуру последнего [5, 8]. Такие слои, неупорядоченно чередуясь с разбухающими пакетами, образуют смешанослойную фазу, присутствие которой в продуктах выветривания основных пород, в связи с иной природой чередующихся пакетов, является их типоморфным признаком. При резком уменьшении количества вермикулитовых пакетов в структуре смешанослойного образования оно (с одновременным резким увеличением количества дефектов в структуре) все более приближается к диоктаэдрическому типу, что также сопровождается усилением роли $\mathrm{Al}$ в октаэдрических позициях структуры этой фазы. Данное смешанослойное образование характеризуется беспорядочным наложением слоев в структуре и пониженными значениями параметра $b(0,894-0,896$ нм) элементарной ячейки. Ему свойственно также слабое разбухание с глицерином после насыщения $\mathrm{K}$, что указывает на относительно высокий заряд слоистых слоев структуры. Анализ вариационных LM/OK-диаграмм показал [24], что, 
несмотря на определенное различие исходных пород основного состава, продукты их выветривания по химичесому составу на данной стадии гипергенного преобразования имеют тенденцию к сближению. Векторы выветривания основных пород исследованных алмазоносных районов СП направлены (рис. 3) к полю бокситов, что обусловлено образованием при их выветривании гидроксидов Al. Происходящее значительное перераспределение Si и вынос его избытка и железа из структуры первичных минералов обусловливает первоначальное развитие каолинита в средних частях наиболее измененных профилей, а в отдельных трубочных телах туфогенных пород (Ан-49) - и гиббсита.

Для установления закономерностей преобразования кимберлитов и определения типоморфных особенностей продуктов их выветривания проведено [8-11, 16-21] комплексное исследование профилей выветривания СП, Восточно-Европейской платформы (ВЕП) и Гвинеи. Для легких фракций образований КВ кимберлитовых пород характерно постоянное присутствие бледно-оливковых и желтовато-зеленых чешуек флогопита и продуктов его изменения (хлорита и вермикулита), обломков серпентина, а также глинисто-карбонатных агрегатов, состоящих преимущественно из смеси глинистых минералов, кальцита и доломита. В сильно химически переработанных продуктах выветривания кимберлитов увеличивается количество пиропа, корродированного по кубоидному типу [1-4]. Нередки в КВ кимберлитов зерна пиропа с белесой рубашкой, столь характерной для древних россыпей района. Как для плотных, так и для выветрелых кимберлитов характерны пиропы с келифитовой каймой. В зависимости от степени выветрелости кимберлитов отмечены различные следы изменения оливина (вплоть до полной его серпентинизации), пироксенов, хромшпинелидов и пикроильменита. В глинистой составляющей продуктов выветривания кимберлитов, кроме содержащихся в легкой фракции серпентина, хлорита и вермикулита, присутствует также монтмориллонит, МГСО и гидрослюда. Судя по значению $b=0,893$ нм, в октаэдрических сетках структуры разбухающих минералов содержатся в основном $\mathrm{Fe}^{3+}$ и Al. В нижних и средних частях КВ кимберлитов эта смешанослойная фаза характеризуется тенденцией к упорядоченному чередованию пакетов. К верхам профилей в ней появляются явные элементы разупорядочения структуры, в лабильных промежутках (как и в монтмориллоните), преобладают $\mathrm{Mg}$ и Са. Во фракции мельче 0,001 мм слабоизмененных кимберлитов (преимущественно зона дезинтеграции) серпентин представлен пластинчатой разновидностью, структура которой состоит из слоев типов А и В [8-12]. Сохраняется минерал вплоть до самых верхов профилей выветривания, где характеризуется только политипом А. При этом для частиц новообразованного политипа (А) вначале характерна округлая глобулярная форма (размер глобул до 0,5 мкм). Глобулы образуются иногда на острых гранях других минералов. Они сочленяются в вытянутые червеподобные сростки длиной в несколько микрометров. Вверх по разрезу обычно увеличиваются размеры частиц новообразованного серпентина и его сростков. Отсюда следует, что морфологические выделения серпентина в породах, не затронутых выветриванием, существенно отличаются от его форм в продуктах гипергенного изменения кимберлитов и родственных им пород. Направление вектора выветривания кимберлитов на вариационной LM-OK-диаграмме [24] занимает (рис. 3) промежуточное положение между полем терригенно-карбонатных образований и пород основного состава, т. е. в продуктах их выветривания с одинаковой вероятностью может идти образование как оксидов, так и каолинита. При этом свойственный слюде в кимберлите политип 1М как менее устойчивый при выветривании обусловливает сравнительно более быстрое накопление в продуктах диоктаэдризации $\mathrm{Al}$, чем выветривание слюды $2 \mathrm{M}_{1}$ в терригенно-карбонатных породах.

Продолжительность периодов корообразования, протекающих при теплом влажном климате и относительно хорошем дренаже территории, существенно влияет на мощность элювиальных толщ и на количество алмазов, высвобождающихся из этих толщ при их образовании, либо непосредственно на кимберлитах, либо в продуктах их ближнего переотложения во вторичных коллекторах. Оценивая с этих позиций изложенные выше данные о древних КВ основных алмазоносных районов СП как в целом, так и в наиболее богатых алмазами МБАР и ДААР, можно отметить, что в позднедевонское-раннекаменноугольное и средне-позднетриасовое время здесь существовали благоприятные условия для интенсивного корообразования. Об этом свидетельствуют, в первую очередь, сохранившиеся от размыва мощные КВ с высокозрелыми верхними горизонтами. Непосредственно в КВ россыпи алмазов формируются только над кимберлитовыми трубками, что приводит к ограниченным их размерам [1-5]. На других породах россыпи не образуются, за исключением случаев, когда субстратом являются вторичные коллекторы алмазов (например, верхнепалеозойские отложения). Поэтому важное значение имеет установление условий размыва и переотложения продуктов КВ при накоплении верхнепалеозойских и мезозойских отложений, детально изученных нами в пределах МБАР, где они одновременно имеют широкое развитие. Следует отметить, что если формирование этих отложений (и в первую очередь их грубообломочных горизонтов) происходило в условиях накопления делювиально-пролювиальных, пролювиально-аллювиальных и озерных фаций (т. е. за счет преимущественно ближнего сноса местного материала), то тогда вблизи кимберлитовых тел формировались россыпи алмазов. При обильном привносе чуждого региону терригенного материала и развитии аллювиальных фаций происходил размыв КВ на кимберлитах, что приводило к выносу обогащенных алмазами продуктов за пределы локальных участков и сильному разубоживанию их за счет “транзитного” неалмазоносного аллювия. В таких условиях образование алмазных россыпей становилось практически невозможным. Переотложение продуктов выветривания вблизи областей денудации и накопление их в основном в пресноводных континентальных водоёмах, а также небольшая мощность сформировавшихся осадочных толщ и незначительные погружения их определили, в частности, слабое гидрохимическое воздействие среды на аллотигенные минералы, а также отсутствие наложенных на них процессов катагенетического преобразования. Эти условия привели к тому, что глинистые минералы верхнепалеозойских и мезозойских осадочных толщ основных алмазоносных районов СП, связанные преимущественно с процессами переотложения различных продуктов выветривания, определенным образом наследуют структурные и кристаллохимические особенности минералов из элювиальных толщ. Это позволяет использовать изложенные выше типоморфные признаки однотипных минералов легкой, тя- 
желой и глинистой фракций, а также геохимические особенности выветрелых пород для идентификации в осадочных толщах продуктов, поступивших из различных источников сноса и связанных с гипергенными изменениями пород различного химического и минералогического состава.

На протяжении позднего палеозоя в МБАР (северо-восточный борт ТВС) унаследованное и некомпенсированное опускание отдельных участков территории привело к образованию ряда конседиментационных депрессий: Ахтарандинской на западе, Улахан-Ботуобинской, охватывающей нижнее течение р. Б. Ботуобии, и Кюеляхской - в верховье р. Кюелях. Между этими депрессиями располагаются участки, испытавшие относительно замедленное опускание территории. Так, на западе района установлено Чернышевское поднятие, а в районе Улу-Тогинской петли р. Вилюй - Улу-Тогинское, совпадающее с осевой линией Улу-Тогинского поднятия. Все это обусловило образование в пределах поднятий и их склонов осадков, обогащенных местным, а в депрессиях - преимущественно чуждым району материалом. В районе пока не обнаружены кимберлитовые трубки, перекрытые верхнепалеозойскими отложениями. Однако находки в базальных горизонтах этих поднятий заметных концентраций алмазов и других индикаторных минералов кимберлитов (ИМК) со специфическими свойствами позволяют предполагать присутствие на этой территории еще неоткрытых коренных источников. В позднедевонское-раннекаменноугольное время неоткрытые пока кимберлитовые диатремы подвергались эрозии и высвободившийся вследствие выветривания кимберлитовый материал формировал россыпи различных генетических типов. Главнейшими образованиями верхнего палеозоя МБАР, в формировании которых значительную роль сыграли позднедевонские-раннекаменноугольные КВ, являлись породы лапчанской $\left(\mathrm{P}_{1} 1\right)$, ботуобинской $\left(\mathrm{P}_{1} \mathrm{bt}\right)$ и боруллойской $\left(\mathrm{P}_{2} \mathrm{br}\right)$ свит. Преобладание в базальных горизонтах лапчанской свить крупнообломочного материала из местных источников сноса (известняки, известковистые песчаники, доломиты и др.), полевошпатово-кварцевый (нередко до кварцевого) состав минералов легкой фракции, обедненный комплекс минералов тяжелой фракции (с преобладанием их аутигенных разностей) указывают на преобладание в составе пород лапчанской свиты материала переотложенной КВ на терригенно-карбонатных породах. В разрезах лапчанской свиты, непосредственно залегающих на КВ терригенно-карбонатных пород, в нижних горизонтах отмечены [8-13, 17-21] максимальные концентрации каолинита и диоктаэдрической гидрослюды $2 \mathrm{M}_{1}$. Однако отмечены случаи, когда в пробах из нижних базальных горизонтов этих толщ указанная гидрослюда отсутствует вообще, подчеркивая неравномерность распределения выветрелого материала данного типа Для пелитовой составляющей лапчанской свиты свойственна также повышенная концентрация $\mathrm{Mg}$-Fe-хлорита, по структурно-морфологическим особенностям близкого к установленному в КВ терригенно-карбонатных пород. Это как содержание и состав грубообломочного материала, а также минеральные парагенезисы легкой, тяжелой и глинистой фракций позволяют утверждать, что в период формирования осадков лапчанской свиты в них преобладали продукты переотложения КВ терригенно-карбонатных пород нижнего палеозоя и кластических образований среднего палеозоя. Значительно меньшую роль играли в этом процессе выветрелые продукты основного и ультраосновного состава.
В грубообломочном комплексе образований ботуобинской свиты отмечено повышенное (до 60 \%) содержание гальки кварцитов. Отсортирован обломочный материал в базальных горизонтах этой свиты обычно плохо. Как и для лапчанской свиты, в базальных горизонтах ботуобинской свиты не отмечены четкие закономерности распределения главнейших минералов легкой, тяжелой и глинистой фракций, что указывает на неравномерное распределение здесь материала древних КВ. Основные породообразующие минералы ботуобинской свиты - кварц и полевые шпаты. Весьма типичны здесь минералы группы эпидота, среди которых, в отличие от лапчанской свиты, преобладает эпидот. Отдельные прослои обогащены чешуйчатыми выделениями биотита, лепидомелана, мусковита и хлорита. Для тяжелой фракции характерно присутствие в различной степени окатанных зерен циркона, турмалина и апатита. В отличие от лапчанской свиты, в нижних горизонтах ботуобинской увеличивается концентрация монтмориллонита, неупорядоченных МГСО и вермикулит-монтмориллонитовых смешанослойных образований (BMCO), что свидетельствует о возрастании в этих горизонтах роли продуктов выветривания пород основного и ультраосновного составов и уменьшении роли продуктов выветривания терригенно-карбонатных пород. На это указывают также сравнительно меньшие концентрации диоктаэдрической гидрослюды $2 \mathrm{M}_{1}$ и каолинита с относительно упорядоченной структурой. Нередко отмечается достаточно высокая концентрация каолинита по всему разрезу свиты, что связано с поступлением его из верхних горизонтов КВ на породах трапповой формации. В грубообломочном материале боруллойской свить несколько увеличивается содержание обломков кварца. Основное отличие пород этой свиты от нижележащих каменноугольно-пермских отложений сводится к широкому присутствию в легкой и тяжелой фракциях слюдистых минералов (биотита, мусковита и лепидомелана). Постоянно присутствуют в этих породах минералы группы эпидота. Отмечены также различия в минеральном составе базальных горизонтов и всего разреза в целом. Так, для проб из базального горизонта свиты характерно отсутствие слюд и хлорита, а также повышенные содержания ильменита, лейкоксена, а иногда и альмандина. В пелитовой составляющей преобладают монтмориллонит, неупорядоченные МГСО и ВМСО, а в проницаемых породах (песчаниках и алевролитах) пойменных и озерно-болотных фаций - и каолинит. Уменьшается содержание гидрослюды и хлорита. Анализ особенностей минерального состава отложений боруллойской свиты позволяет считать, что в процессе их формирования доминирующее влияние оказали продукты выветривания основных пород среднепалеозойского возраста. Выветрелые толщи терригенно-карбонатных пород нижнего палеозоя, которые к тому времени в значительной степени были уже перекрыты отложениями лапчанской и ботуобинской свит, играли подчиненную роль. Следует отметить, что некоторое количество встреченных в боруллойской свите минералов легкой, тяжелой и глинистой фракций может быть связано также с перемывом и переотложением пород средне-позднекаменноугольного и раннепермского возраста. Это касается незначительного количества монтмориллонита и ассоциирующих с ним смешанослойных образований. Неравномерное распределение по разрезу свиты продуктов КВ терригенно-карбонатных пород подчеркивается особенностями гидрослюды $2 \mathrm{M}_{1}$ и каолинита. 
В мезозойское время в пределах большей части МБАР территориально совпадающей с АВНМП, существовали две структурно-формационные зоны, которые характеризовались специфическими особенностями строения, наложившими определенный отпечаток на формирующиеся осадки. Материал древних КВ попадал в бассейны седиментации в период формирования здесь континентальных отложений иреляхской $\left(\mathrm{T}_{3}-\mathrm{J}_{1} \mathrm{ir}\right)$ и укугутской $\left(\mathrm{J}_{1} \mathrm{uk}\right)$ свит, а также прибрежно-морских плинсбахского $\left(\mathrm{J}_{1} \mathrm{p}\right)$ и тоарского $\left(\mathrm{J}_{1} \mathrm{t}\right)$ ярусов. В отложениях иреляхской свиты псефитовые породы представлены [6-8] гравелитами, конгломератами, брекчиями, а также рыхлыми галечно-щебеночными отложениями. В основании разреза они обычно образуют линзы и прослои, а по разрезу отмечаются только рассеянные гальки и гравий. Наибольшая мощность прослоев грубообломочных пород отмечена в нижней толще иреляхской свиты в пределах приосевой части АВНМП, где обломочный материал представлен преимущественно (до 80 \%) сравнительно хорошо окатанными разнообразными (метаморфическими, кислыми, средними, щелочными изверженными и интрузивными) чуждыми району породами. Обломки местных пород (различно изменённые терригенно-карбонатные породы нижнего палеозоя и траппы) окатаны слабо. Широко распространены здесь псаммиты, представленные граувакковыми аркозами, полевошпат-кварцевыми и кварц-полевошпатовыми граувакками. Чисто алевритовые и глинистые породы в разрезах приосевой части прогиба встречаются сравнительно редко. Петрографический состав крупнообломочного материала в иреляхской свите этой части прогиба, как и данные пофракционных минералогических исследований, указывают на незначительную концентрацию здесь продуктов перемыва и переотложения древних КВ. Для иреляхских отложений вдоль отмеченной полосы АВНМП характерно развитие глин с прослоями тонкозернистых песков и алевритов. Более полные разрезы свиты сохранились здесь в Иреляхской и Мачобинской депрессиях. Стратотипом иреляхских отложений этого района можно считать [8-13] разрезы древней россыпи, расположенной в локальной впадине на борту Иреляхской мезозойский депрессии. Повышенная концентрация продуктов переотложения древних КВ отмечается в нижних горизонтах свиты. Обычно в таких участках увеличивается крупность песка и появляется примесь галечного и гравийного материала. Нередко в нижних частях разрезов встречаются глыбы и щебень по-разному выветрелых терригенно-карбонатных пород нижнего палеозоя и значительная концентрация ИМК (пиропа и пикроильменита). Вверх по разрезу содержание выветрелого материала резко уменьшается. Неравномерно распределяется и выветрелый материал кимберлитов. При этом наблюдается и различная дальность его переноса, что, кроме различного морфологического облика ИМК и самих алмазов, подтверждается и установлены нами [8-11] присутствием здесь некоторых вторичных минералов, характерных для кимберлитов: Fe-Mg-хлорита, вермикулита и серпентина политипной модификации А. О незначительном переносе этих минералов свидетельствуют их структурно-морфологические особенности и приуроченность к иреляхским алмазоносным россыпям МБАР, сформированным вблизи от коренных месторождений. В отличие от этого, отложения укугутской свить в целом характеризуются незначительной концентрацией продуктов переотложения древних КВ. Нижние горизонты укугутской свиты сложены довольно мощной толщей конгломератов, галечный материал в которых представлен разнообразными изверженными, метаморфическими и осадочными породами. Подавляющее большинство (до 90 \%) этих образований являются чуждыми для района. В депрессиях траппового плато (северо-западный борт прогиба) отложения укугутской свиты более обогащены продуктами переотложения древних КВ, чем в центральной части прогиба, но значительно меньше, чем иреляхские породы. В отложениях укугутской свиты северо-западного борта прогиба развиты гравелиты, отличающиеся от иреляхских большей грубозернистостью и иным составом обломков, среди которых не встречены пелитизированные эффузивы. В укугутских отложениях заметно больше гравийных зерен кварца и полевых шпатов (ортоклаза и микроклина). Довольно характерны для укугутских отложений песчаные образования. В отличие от иреляхской свиты в укугутских появляются сильно хлоритизированные обломки эффузивов или туфов с реликтовыми порфировыми и кристалловитрокластическими структурами. Алевритовые и глинистые породы в укугутских разрезах встречаются сравнительно редко и обычно залегают в виде отдельных прослоев в различных частях изученной территории. Иногда в разрезе отмечается тонкое переслаивание алевролитов, глин и мелкозернистых песчаных пород, а в алевритах наблюдаются мелкие частицы хлоритизированных пород, по форме и структуре напоминающие пелитизированные обломки, встреченные в иреляхской свите, но отличающиеся от них интенсивным зеленым цветом и значительными концентрациями хлорита. В целом результаты комплексного изучения вещественного состава укугутских отложений показывают, что они слабо обогащены продуктами переотложения КВ. Только в локальных депрессиях северо-западного борта прогиба, в случае непосредственного залегания их на КВ терригенно-карбонатных пород и траппов, в нижних горизонтах увеличивается концентрация аллотигенных глинистых минералов, связанных с выветриванием указанных пород. В отложениях плинсбахского яруса крупнообломочные породы пользуются ограниченным распространением. Их петрографический состав менее разнообразен, чем в укугутской свите, и обычно тесно связан с составом местных пород. Довольно широко развиты в плинсбахских отложениях псаммитовые образования (преимущественно аркозовой и граувакковой групп), что характерно и для аналогичных пород тоарского яруса. От аналогичных образований укугутской свиты отложения плинсбахского и тоарского ярусов отличаются более высоким содержанием литоидных обломков и частично их составом. Алевролиты плинсбахского яруса нередко переслаиваются с песчаными образованиями, образуя алевро-песчанистый ритмолит. Они обычно плохо сортированы, имеют полимиктовый состав и повышенную углистость. В таких алевритах обычно много хлоритизированных обломков слюд и продуктов их изменения - хлоритов. Для тоарских отложений также характерны алевритовые породы, отличающиеся значительной крупностью частиц, большими примесями глинистого вещества, полимиктовым составом и обилием скоплений хлорита и сидерита, а также заметно меньшим содержанием слюд и обломков неизмененных пород. Для отложений плинсбахского и тоарского ярусов в целом не свойственна высокая концентрация продуктов выветривания других пород, что подтверждается особенностями вещественного со- 
става этих толщ. Это подчеркивается незначительной примесью в них аллотигенных глинистых минералов. В период формирования этих отложений небольшую роль играли только продукты древних КВ основных пород, на что указывает присутствие в пелитовой составляющей аллотигенного монтмориллонита и смешанослойных образований, характерных для данного типа выветрелых пород.

Таким образом, проведенные исследования позволяют утверждать, что позднедевонские-раннекаменноугольные и средне-позднетриасовые эпохи характеризуются активным развитием процессов корообразования, протекающих в условиях теплого и влажного климата, в результате чего образовались соответствующие формации КВ. Сложный многокомпонентный состав исходных пород в древних КВ СП (за исключением терригенно-карбонатных пород), содержащий ди- и триоктаэдрические минералы, в структуре которых есть трех- и двухвалентные породообразующие элементы, обусловил замедленное преобразование первичного материала. В результате формирования разрезов КВ зачастую приостановилось на начальных стадиях. Развитие неполных профилей выветривания вызвано прежде всего слабым выносом двухвалентных катионов из первичных минералов. Поэтому вновь возникающие фазы будут диоктаэдричными и нередко сохраняют смешанный состав структурных катионов. Поскольку в продуктах выветривания преобладает пелитовая составляющая, важнейшими типоморфными признаками глинистых образований в изученных КВ являются: а) повсеместное присутствие диоктаэдрической гидрослюды $\left(2 \mathrm{M}_{1}\right)$ в $\mathrm{KB}$ терригенно-карбонатных пород и её постоянная ассоциация в наиболее зрелых профилях с каолинитом относительно наиболее упорядоченной структуры, чем у каолинита, образовавшегося за счет других пород; б) постоянное наличие в разрезах КВ пород трапповой формации (долериты, туфы и туфогенные образования) наряду с ди- и триоктаэдрическим монтмориллонитом, а также неупорядоченным ВМСО, в той или иной мере неупорядоченного каолинита, ассоциирующего в КВ туфогенных пород с галлуазитом (при полном отсутствии в продуктах выветривания слюдоподобных минералов); в) содержание в КВ кимберлитов совместно с поликатионным монтмориллонитом, значительного количества триоктаэдрического хлорита (пакеты $\delta^{\prime}$ и $\delta$ ), серпентина (структурные типы А и В) и в значительной степени измененного флогопита, в том числе и связанной с ними гидрослюды 1 М. Кроме того, установлено, что в изученных КВ смешанослойным образованиям в зависимости от природы исходных минералов, за счет которых они возникли, свойственны как различные виды переслаивания пакетов, так и неодинаковый химический состав в одном и том же типе указанных фаз, что является их важным типоморфным признаком. В частности, ВМСО развито в породах, в которых отсутствуют минералы слюдоподобного типа, а из трехэтажных разновидностей встречается в основном вермикулит. Соответственно МГСО приурочены к породам, содержащим минералы трехэтажного типа с $\mathrm{K}$ в межслоевых промежутках, т. е. типично слюдистого типа. По кристаллохимическим особенностям указанная смешанослойная фаза в КВ кимберлитов существенно отличается от аналогичной в измененных терригенно-карбонатных породах. Это связано с иными природой и химическим составом исходного материала, за счет которых в кимберлитах возникло указанное образование, представленное продуктами диоктаэдризации флогопита и дальнейшей его деградации, что обусловливает свойственный указанным продуктам высокий отрицательный межслоевой заряд, который наследуется от исходной слюдистой структуры. Такие особенности смешанослойной фазы, характеризующейся специфической неоднородностью слагающих её пакетов, являются важным признаком продуктов выветривания кимберлитов. Отмеченные различия в типоморфном составе каждого типа коры выветривания можно успешно использовать при совершенствовании методики поисковых работ на алмазы.

\section{ЛИТЕРАТУРА}

1. Афанасьев В. П., Зинчук Н. Н. Минерагения древних россыпей алмазов восточного борта Тунгусской синеклизы//Геология и геофизика. - 1987. - № 1. - С. 90-96.

2. Афанасьев В. П., Зинчук Н. Н. Основные литодинамические типы ореолов индикаторных минералов кимберлитов и обстановки их формирования//Геология рудных месторождений. - 1999. - Т. 41. - № 3. - C. 281-288.

3. Афанасьев В. П., Зинчук Н. Н., Коптиль В. И. Полигенез алмазов в связи с проблемой коренных россыпей северо-востока Сибирской платформы//Доклады Академии наук. - 1998. - Т. 361. - № 3. - C. 366-369.

4. Афанасьев В. П., Зинчук Н. Н., Логвинова А. Н. Особенности распределения россыпных алмазов, связанных с докембрийскими источниками//Записки Российского минералогического общества. - 2009. - T. 138. - № 2. - С. 1-13.

5. Афанасьев В. П., Зинчук Н. Н., Тычков С. А. Проблема докембрийской алмазоносности Сибирской платформы//Вестник Воронежского госуниверситета. Геология. - 2002. - № 1. - С. 19-36.

6. Гладков А. С., Борняков С. А., Манаков А. В., Матросов В. А. Тектонофизические исследования при алмазопоисковых работах. Методическое пособие. - М.: Научный мир, 2008. - 175 с.

7. Дукардт Ю. А., Борис Е. И. Авлакогенез и кимберлитовый магматизм. - Воронеж: ВГУ, 2000. - 161 с.

8. Зинчук Н. Н. Состав и генезис глинистых минералов в верхнепалеозойских осадочных толщах восточного борта Тунгусской синеклизы//Геология и геофизика. - 1981. - № 8. - С. 22-29.

9. Зинчук Н. Н. Сравнительная характеристика вещественного состава коры выветривания кимберлитовых пород Сибирской и Восточно-Европейской платформ//Геология и геофизика. - 1992. № 7. - C. 99-109.

10. Зинчук Н. Н., Борис Е. И., Яныгин Ю. Б. Особенности минерагении алмаза в древних осадочных толщах (на примере верхнепалеозойских отложений Сибирской платформы). - М.: МГТ, 2004. - 172 с.

11. Зинчук Н. Н., Зуев В. М., Коптиль В. И., Чёрный С. Д. Стратегия ведения и результаты алмазопоисковых работ//Горный вестник. - 1997. - № 3. - С. 53-57.

12. Зинчук Н. Н., Коптиль В. И., Борис Е. И., Липашова А. Н. Типоморфизм алмазов из россыпей Сибирской платформы как основа поисков алмазных месторождений//Руды и металлы. - 1999. № 3. - С. 18-31.

13. Зинчук Н. Н., Мельник Ю. М., Серенко В. П. Апокимберлитовые породы//Геология и геофизика. - 1987. - № 10. - С. 66-72.

14. Зинчук Н. Н., Савко А. Д., Крайнов А. В. Кимберлиты в истории Земли. Методическое пособие для магистров по специализации "Геологическая съёмка и поиски месторождений полезных ископаемых"//Труды НИИГ Воронежского ун-та. - Воронеж: ВГУ, 2013. - Т. $68 .-99$ c.

15. Квасница В. Н., Зинчук Н. Н., Коптиль В. И. Типоморфизм микрокристаллов алмаза. - М.: Недра, 1999. - 224 с.

16. Котельников Д. Д., Домбровская Ж. В., Зинчук Н. Н. Основные закономерности выветривания силикатных пород различного химического и минералогического типа//Литология и полезные ископаемые. - 1995. - № 6. - С. 594-601.

17. Котельников Д. Д., Зинчук Н. Н. Типоморфные особенности и палеогеографическое значение слюдистых минералов//Известия ВУЗов. Геология и разведка. - 1996. - № 1. - С. 53-61.

18. Котельников Д. Д., Зинчук Н. Н. Особенности глинистых минералов в отложениях различных осадочных формаций//Известия ВУЗов. Геология и разведка. - 1997. - № 2. - С. 53-63. 
19. Котельников Д. Д., Зинчук Н. Н. Условия накопления и постседиментационного преобразования глинистых минералов в отложениях терригенной формации//Бюллетень Московского общества испытателей природы. Отдел геологический. - 2001. - Т. 76 - № 1. - C. $45-53$.

20. Котельников Д. Д., Зинчук Н. Н. Об аномалии общей схемы преобразования разбухающих глинистых минералов при погружении содержащих их отложений в стратисферу//Вестник Воронежского госуниверситета. Серия геология. - 2003. - № 2. C. $57-68$.

21. Котельников Д. Д., Зинчук Н. Н., Кузьмин В. А. Морфогенетические разновидности каолинита в корах выветривания и осадочном чехле земной коры. Статья 1 . Механизм образования каолинита в корах выветривания различных петрохимических типов пород//Известия ВУЗов. Геология и разведка. - 2006. - № 5. C. $19-25$.

22. Мацюк С. С., Зинчук Н. Н. Оптическая спектроскопия минералов верхней мантии. - М.: Недра, 2001. - 428 с.

23. Харькив А. Д., Зуенко В. В., Зинчук Н. Н., Крючков А. И., Уханов А. В., Богатых М. М. Петрохимия кимберлитов. - М.: Недра, 1991. - 304 c.

24. Хитров В. Г., Зинчук Н. Н., Котельников Д. Д. Применение кластер-анализа для выяснения закономерностей выветривания пород различного состава//Доклады АН СССР. - 1987. - Т. 296. № 5. - C. 1228-1233.

25. Afanasev V. P., Zinchuk N. N., Griffin V. L., Natapov L. M., Matuchyan G. A. Diamond prospects in the Southwestern plankt of the Tungusk Sineklise//Geology of ore Deposits. - 2005. - Vol. 47. - № 1. - P. 45-62.

26. Vasilenko V. B., Kuznetsova L. G., Volkova N. I., Zinchuk N. N., Krasavchikov V. O. Diamond potential estimation based on Kimberlite major element chemistry//Journal of Geochemical Exploration. - 2002. - Vol. 76. - № 2. - P. 93-112.

27.Vasilenko V.B., Kuznetsova L. G., Zinchuk N. N. On the Correlation between the Compositions of mantle Inclusions and Petrochemical Warieties of kimberlites in Yakutian Diatremes//Petrology. - 2001. - Vol. 9. - № 6. - P. 576-588.

28. Grachanov S. A., Zinchuk N. N., Sobolev N.V. The age of Predictable primary diamond sources in the Northeastern Sibirian Platform//Doklady Eart Sciences. - 2015. - Vol. 465. - № 2. - P. $1297-$ 1301.

29. Serov I. V., Garanin V. K., Zinchuk N. N., Rotman A. Ya. Mantle Sources of the kimberlite Vorcanism of the Sibirian Platform//Petrology. - 2001. - Vol. 9. - № 6. - P. 576-588.

\section{REFERENCES}

1. Afanasev V. P., Zinchuk N. N. Minerageny of ancient placers of diamonds on the eastern side the Tunguska syneclise//Geologija i geofizika - 1987. - № 1. - P. 90-96. (In Russian).

2. Afanasev V. P., Zinchuk N. N. Main types of litodinamic tipe of kimberlite indication minerals and the conditions of their formation/ Geologija rudnyh mestorosdenij. - 1999. - Vol. 41. - № 3. - P. 281-288. (In Russian).

3. Afanasev V. P., Zinchuk N. N., Koptil V. I. Poligines of diamonds in connection nith the problem of primary placers of the north-cast of the Siberian platform//Doklady Akademii nauk. - 1998. - Vol. 361. - № 3. P. 366-369. (In Russian).

4. Afanasev V. P., Zinchuk N. N., Logvinova A. N. Distribution features of placer diamonds associatet with the Precambrian source// Zapiski Rossijskogo mineralogicheskogo obshhestva. - 2009. - Vol. 138. - № 2. - P. 1-13. (In Russian).

5. Afanasev V.P., Zinchuk N. N., Tychkov S. A. The problem of dokembriy diamond content of the Sibirian platform//Vestnik Voronezhskogo gosuniversiteta. Geologija. - 2002. - № 1. - P. 19-36. (In Russian).

6. Gladkov A. S., Bornjakov S. A., Manakov A. V., Matrosov V. A. Tektonophisical research during diamond prospecting. Toolkit. - Moskva: Nauchnyj mir, 2008. - 175 p. (In Russian).

7. Dukardt Ju. A., Boris E. I. Avlacogenesis and kimberlite magmatism. - Voronezh: VGU, 2000. - 161 p. (In Russian).

8. Zinchuk N. N. Composition and genesis of clay minerals in the Upper Paleozoic sedimentary strata of the castern side of the Tunguska syneclise//Geologija i geofizika. - 1981. - № 8. - P. 22-29. (In Russian).

9. Zinchuk N. N. Comparative characteristics of material composition of kimberlite rocks' crusts of weathering of the Siberian and
East-European platforms//Geologija i geofizika. - 1992. - № 7. - P. 99 109. (In Russian).

10. Zinchuk N. N., Boris E. I., Yanygin Yu. B. Peculiarities of diamond mineralogene in ancient sedimentary talits by the example of the upper Paleozoic Sediments the Siberian platform. - Moskva: MGT, 2004. - 172 p. (In Russian)

11. Zinchuk N. N., Zuev V. M., Koptil V. I., Chernyj S. D. Diamond management strategy and results//Gornyj vestnik. - 1997. - № 3. P. 53-57. (In Russian).

12. Zinchuk N. N., Koptil V. I., Boris E. I., Lipashova A. N. Typomorphism of diamonds from placers of the Siberian platform as the basis for prospecting of diamond deposits//Rudy i metally. - 1999. - № 3 . - P. 18-30. (In Russian).

13. Zinchuk N. N., Melnik Yu. M., Serenko V. P. Apokimberlite rocks// Geologija i geofizika. - 1987. - № 10. - P. 66-72. (In Russian).

14. Zinchuk N. N., Savko A. D., Krajnov A.V. Kimberlites in the Earth history//Trudy NIIG Voronezhskogo universiteta. - Voronezh: VGU, 2013. - Vol. 68. - 99 p. (In Russian).

15. Kvasnica V. N., Zinchuk N. N., Koptil V. I. Typomorphism of diamond microcrystals. - Moskva: Nedra, 1999. - 224 p. (In Russian).

16. Kotelnikov D. D., Dombrovskaja Zh. V., Zinchuk N. N. Basic laws of weathering of silicate rocks of various chemical and mineralogical types//Litologija i poleznye iskopaemye. - 1995. - № 6. - P. 594-601. (In Russian).

17. Kotelnikov D. D., Zinchuk N. N. Typomorphic features and paleogeographic significance of micaceous minerals//Izvestija VUZov. Geologija i razvedka. - 1996. - № 1. - P. 53-61. (In Russian).

18. Kotelnikov D. D., Zinchuk N. N. Features of Clay minerals in sediments of various sedimentary formations//Izvestija VUZov. Geologija i razvedka. - 1997. - № 2. - P. 53-63. (In Russian)

19. Kotelnikov D. D., Zinchuk N. N. Conditions for the accumulation and postsedimentary transformation of clay minerals in the sediments of the terrigenous formation//Bjulleten Moskovskogo obshhestva ispytatelej prirody. Otdel geologicheskij. - 2001. - Vol. 76. - № 1. - P. 45-53. (In Russian)

20. Kotelnikov D. D. Zinchuk N.N. Anomalies of the generals of transformation of swellable clay minerals where the sediments containing them are immersed in the stratisphere//Vestnik Voronezhskogo gosuniversiteta. Serija geologija. - 2003. - № 2. - P. 57-68. (In Russian).

21. Kotelnikov D. D., Zinchuk N. N., Kuzmin V. A. Morphogenetic varieties of kaolinite in weathering crusts and sedimentary cover of the earth's crust. Article 1. Mechanism of kaolinite formation in the weathering crusts of various petrochemical types of rocks//Izvestija VUZov. Geologija i razvedka. - 2006. - № 5. - P. 19-25. (In Russian).

22. Matsuk S. S., Zinchuk N. N. Optical spectroscopy of minerals of the upper mantle. - Moskva: Nedra, 2001. - 428 p. (In Russian).

23. Harkiv A. D., Zuenko V. V., Zinchuk N. N., Krjuchkov A. I., Uhanov A. V., Bogatyh M. M. Petrochemistry of kimberlites. - Moskva: Nedra, 1991. - 304 p. (In Russian).

24. Chitrov V. G., Zinchuk N. N., Kotelnikov D. D. Application of cluster-analysis for clearing out regularities of various composition rocks weathering//Doklady AN SSSR. - 1987. - Vol. 296. - № 5. - P. 1228-1233. (In Russian).

25. Afanasev V. P., Zinchuk N. N., Griffin V. L., Natapov L. M., Matuchyan G. A. Diamond prospects in the Southwestern plankt of the Tungusk Sineklise//Geology of ore Deposits. - 2005. - Vol. 47. - № 1 - P. 45-62.

26. Vasilenko V. B., Kuznetsova L. G., Volkova N. I., Zinchuk N. N., Krasavchikov V. O. Diamond potential estimation based on Kimberlite major element chemistry//Journal of Geochemical Exploration. - 2002. - Vol. 76. - № 2. - P. 93-112.

27. Vasilenko V. B., Kuznetsova L. G., Zinchuk N. N. On the Correlation between the Compositions of mantle Inclusions and Petrochemical Warieties of kimberlites in Yakutian Diatremes//Petrology. - 2001. - Vol. 9. - № 6. - P. 576-588.

28. Grachanov S. A., Zinchuk N. N., Sobolev N. V. The age of Predictable primary diamond sources in the Northeastern Sibirian Platform// Doklady Eart Sciences. - 2015. - Vol. 465. - № 2. - P. 1297-1301.

29. Serov I. V., Garanin V. K., Zinchuk N. N., Rotman A. Ya. Mantle Sources of the kimberlite Vorcanism of the Sibirian Platform//Petrology. - 2001. - Vol. 9. - № 6. - P. 576-588.

Рукопи с о тримано 5.10 .2020 . 